\title{
PENINGKATKAN KOMPETENSI GURU SEKOLAH DASAR DALAM MENGIMPLEMENTASIKAN STANDAR PROSES PEMBELAJARAN MELALUI SUPERVISI KOLEGIAL TEKNIK KUNJUNGAN ANTAR KELAS
}

\author{
Wardana \\ SD Negeri 3 Taruman, UPTD Pendidikan Klambu, Grobogan, Jawa Tengah \\ wardana.85@gmail.com
}

\begin{abstract}
ABSTRAK
Penelitian ini bertujuan untuk (a) mengetahui peningkatan kompetensi guru dalam mengimplementasikan standar proses pembelajaran dan pembelajaran kooperatif kolaboratif dalam rencana pelaksanaan pembelajaran setelah kunjungan antar kelas. (b) mengetahui peningkatan kompetensi guru dalam mengimplementasikan standar proses pembelajaran dan pembelajaran pembelajaran koperatif kolaboratif dalam pelaksanaan pembelajaran setelah kunjungan antar kelas. Penelitian tindakan ini dilakukan dua siklus, setiap siklus terdiri dari empat tahap, yaitu: perencanaan, pelaksanaan tindakan, observasi dan refleksi. Sasaran penelitian ini adalah Guru Kelas 5 tahun pelajaran 2016/2017. Dari hasil analisis didapatkan bahwa kompetensi guru dalam mengimplementasikan standar proses pembelajaran dan pembelajaran kooperatfi kolaboratif dalam Rencana Pelaksanaan Pembelajaran mengalami peningkatan yaitu siklus I (61,67\%), siklus II (75,00\%), sedangkan kompetensi guru dalam mengimplementasikan pembelajaran kooperatif kolaboratif dalam Pelaksanaan Pembelajaran mengalami peningkatan yaitu siklus I (65\%), siklus II (75,56\%). Simpulan dari penelitian ini adalah supervisi kolegial lewat kunjungan antar kelas dapat berpengaruh positif terhadap peningkatan kompetensi guru dalam mengimplementasikan standar proses dan pembelajaran kooperatif kolaboratif dalam rencana pelaksanaan pembelajaran dan pelaksanaan pembelajaran.
\end{abstract}

Kata Kunci : Standar proses, Supervisi Kolegial, Kunjungan antar kelas.

\section{ABSTRACT}

The aims of this research are: (a) Want to know the improvement of teacher competence in implementing learning process standard and cooperative cooperative learning in learning plan after class visit. (b) Want to know the improvement of teacher competence in implementing learning process standard and cooperative learning cooperative learning in learning 
implementation after class visit. This action research is conducted two cycles, each cycle consists of four stages, namely: planning, action implementation, observation and reflection. The target of this research is the Class 5 Teachers of the year 2016/2017. From the analysis results obtained that the competence of teachers in implementing learning process standard and cooperative cooperative learning in the Learning Implementation Plan has increased that is cycle I (61.67\%), cycle II (75.00\%), while teacher competence in implementing cooperative cooperative learning in Implementation of Learning has increased that is cycle I (65\%), cycle II (75,56\%). The conclusion of this research is that collegial supervision through classroom visits can positively influence the improvement of teacher competence in implementing collaborative cooperative process standard and learning in the implementation plan of learning and implementation of learning.

Keywords : Standar proses, Supervisi Kolegial, Kunjungan antar kelas. 


\section{PENDAHULUAN}

Kualitas (quality) menjadi kata kunci dalam rangka memberikan pendidikan yang berkualitas, segala upaya tenaga pendidik dan kependidikan bermuara pada bagaimana mendisain pengelolaan pendidikan agar benar-benar efektif menjawab tantangan jaman yang terus berkembang. Sementara itu kualitas pendidikan akan lebih banyak ditentukan seberapa besar kualitas pembelajaran di institusi pendidikan berlangsung.

Tuntutan kualitas tersebut menuntut guru yang kreatif, profesional dan menyenangkan yang harus memiliki konsep dan cara untuk mendongkrak kualitas pembelajaran. Oleh karena itu guru dituntut untuk memiliki kemampuan mengembangkan pendekatan dan memilih metode pembelajaran yang efektif. Hal ini penting terutama untuk menciptakan iklim pembelajaran yang kondusif dan menyenangkan yang pada muaranya akan memberikan hasil yang berkualitas. Guru dituntut untuk menciptakan suasana belajar sedemikian rupa, sehingga siswa bekerja sama secara gotong royong (cooperative learning). Untuk menciptakan situasi yang diharapkan pada pernyataan diatas seoarang guru harus mempunyai syarat-syarat apa yang diperlukan dalam mengajar dan membangun pembelajaran siswa agar efektif di kelas, saling bekerjasama dalam belajar sehingga tercipta suasana yang menyenangkan dan saling menghargai (demokratis ), diantaranya :

Pemerintah dalam hal ini Departemen Pendidikan Nasional melalui Permendiknas No 41 tahun 2007 telah menerbitkan Standar Proses sebagai bagian dari stabdarisasi Nasional di bidang pendidikan. Standar Proses membawa implikasi yang amat luas bagi penyelenggaraan pendidikan khususnya di sekolah dasar. Maka menjadi kewajiban bersama baik tenaga pendidik maupun tenaga non kependidikan bekerjasama untuk dapat melaksanakan ketentuan-ketentuan yang ada dalam standar peroses tersebut agar pembelajaran bisa berlangsung sesuai ketentuan yang berlaku.

Di sisi lain dalam rangka mendukung proses pembelajaran guru selain harus menyusun perangkat pembelajaran juga harus mengerjakan sejumlah administrasi kelas seperti yang disyaratkan dalam Pedoman Admnistrasi Sekolah Dasar sebagai salah satu komponen untuk menjamin adanya standar mutu penyelenggaraan pendidikan sekolah dasar. Pedoman ini mengacu pada Kepmendiknas nomor 053/U/2001 tentang Pedoman Penyusunan Standar Pelayanan Minimal 
Penyelenggaraan Persekolahan Bidang Dikdasmen dan kebijakan pemerintah mengenai Manajemen Peningkatan mutu berbasis sekolah.

Dari hasil supervisi yang dilakukan oleh Para Kepala Sekolah Dasar di Kabupaten Grobogan pada kenyataannya ditemukan bahwa administrasi guru yang terdiri dari perangkat pembelajaran seperti dokumen Kurikulum Tingkat Satuan Pendidikan (KTSP) dan dokumen administrasi guru kelas belum dikerjakan seperti apa yang disyaratkan.

KTSP secara fisik ada namun bukan buatan sendiri dan disusun tidak melalui prosedur penyusunan yang mesti dilakukan. Dokumen KTSP berupa Silabus, Program Tahunan, Program Semester, Rencana Pelaksanaan Pembelajaran(RPP) serta Ketuntasan Belajar Minimal masih copy paste dengan polesan cut and glue. RPP semester 1(satu) belum tersusun seluruhnya karena masih pada kisaran $50 \%$ terkerjakan. Sedangkan Adminsitrasi Guru Kelas masih dikerjakan di kisaran 60\%. Padahal ideal Administrasi Pembelajaran dan Administrasi Guru Kelas harus 100\% dikerjakan. Hal itupun belum dikaji seberapa besar isi Rencana Pelaksanaan Pembelajaran sesuai dengan ketentuan standar proses dan seberapa benar pelaksanaan rencana pembelajaran dilaksanakan sesuai ketentuan standar proses. Pada saat yang sama ketentuan standar proses (bagian standar Pendidikan nasional) membawa implikasi yang sangat luas terhadap proses pembelajaan. Dari uraian di atas, nampak kesenjangan antara ideal tuntutan standar proses dan pedoman admnistrasi guru kelas dengan realitas. Disamping itu dari hasil supervisi rencana pelaksanaan pembelajaran dan pelaksanaannya tidak memenuhi standar kualitas. Hal itu terjadi memang harus diakui bahwa banyak faktor yang menjadi penyebabnya, namun jika tidak ada tindakan yang dilakukan maka akan timbul akibat terhadap peserta didik.

Kepala Sekolah, guru dan stakeholders mempunyai tanggung jawab terhadap peningkatan mutu pembelajaran di sekolah terutama guru sebagai ujung tombak dilapangan (di kelas) karena bersentuhan langsung dengan peserta didik dalam proses pembelajaran. Guru mempunyai tugas dan tanggung jawab yang sangat besar.

Bagaimana menjaga kondisi tersebut terpelihara dan berkembang dengan baik? Salah satu alternatif jawaban adalah melalui supervisi pendidikan. Melalui supervisi pendidikan sebagai bagian dari kegiatan manajemen oleh kepala sekolah dapat diketahui apakah program yang direncanakan sudah berjalan sesuai ketentuan 
yang berlaku apa tidak disamping itu juga untuk mengetahui seberapa besar kualitas pembelajaran dilaksanakan. Dengan pendekatan, teknik, model dan jenis supervisi yang disesuaikan dengan tujuan kepengawasan yang diharapkan maupun kondisi sasaran maka upaya perbaikan itu dapat dilaksanakan.

Supervisi kolegial sebagai bentuk supervisi kesejawatan yang memiliki beberapa keunggulan dalam meningkatkan mutu pembelajaran, oleh karena itu perlu dioptimalkan guna peningkatan kualitas tenaga kependidikan maupun peningkatan mutu atau kualitas sekolah. Berdasarkan pemikiran tersebut perlu dilakukan upaya dalam bentuk tindakan sekolah dengan memanfaatan pertemuan gugus agar tergali kembali konsep dan pemahaman guru dan kepala sekolah untuk mencapai mutu atau kualitas sekolah yang diharapkan.

Tujuan dari penelitian ini adalah : (a) Ingin mengetahui peningkatan kompetensi guru dalam mengimplementasikan standar proses pembelajaran dan pembelajaran kooperatif kolaboratif dalam rencana pelaksanaan pembelajaran setelah kunjungan antar kelas. (b) Ingin mengetahui peningkatan kompetensi guru dalam mengimplementasikan standar proses pembelajaran dan pembelajaran pembelajaran koperatif kolaboratif dalam pelaksanaan pembelajaran setelah kunjungan antar kelas.

\section{METODE PENELITIAN}

Subyek penelitian ini adalah para guru kelas 5 di SD Negeri 3 Taruman Kecamatan Klambu Kabupaten Grobogan. Tempat penelitian adalah tempat yang digunakan dalam melakukan penelitian untuk memperoleh data yang diinginkan. Penelitian ini bertempat SD di Kecamatan Klambu Kabupaten Grobogan dengan memanfaatkan Kelompok Kerja Kepala Sekolah (KKKS) dan Kelompok Kerja Guru (KKG) di UPTD Pendidikan Kecamatan Klambu Kabupaten Grobogan. Adapun waktu pelaksanaan pada akhir semester 1, tahun pelajaran 2016/2017.

Penelitian ini bertempat di UPTD Pendidikan Kecamatan Klambu Kabupaten Grobogan. Tempat ini sengaja dipilih karena di samping sekolah peneliti, wilayahnya juga relatif dekat, berdasarkan profil sekolah dan penilaian kinerja memiliki tingkat atau kualitas kinerja yang sama.

Waktu penelitian adalah waktu berlangsungnya penelitian atau saat penelitian ini dilangsungkan. Penelitian ini dilaksanakan pada bulan Agutustus sampai dengan Oktober 2016. 
Melalui kunjungan antarkelas setiap guru akan memperoleh pengalaman baru tentang proses pembelajaran, pengelolaan kelas, dan metode pembelajaran. Kunjungan antarkelas akan lebih efektif jika disertai kesempatan berdialog tentang hal-hal yang menarik perhatian guru tamu dengan guru yang dikunjungi. Pada kunjungan antarkelas mungkin guru berkesempatan untuk berkunjung berkali-kali dengan mengadakan magang. Guru magang dapat berperan serta secara aktif di kelas sehingga dapat langsung mengalami dan mendiskusikan setiap kegiatan pembelajaran. Dengan demikian guru magang dapat berkomunikasi secara intensif dengan guru kelas.

Tahapan selama kunjungan kelas adalah 1) tahap pertama, mengamati kegiatan pembelajaran di kelas yang dikunjungi, 2) tahap kedua, menyiapkan kegiatan pembelajaran bersama-sama dengan guru kelas, dan 3) tahap ketiga, melakukan kegiatan pembelajaran bersama dengan guru kelas yang bertindak sebagai pengamat dan bila perlu memberikan bantuan langsung dalam suatu pengajaran tim. Tahap selanjutnya dapat mengulangi tahap tersebut secara sistematis dan berulang.

\section{HASIL PENELITIAN DAN PEMBAHASAN}

\section{Deskripsi Setting Penelitian}

\section{Deskripsi Kondisi Awal}

Belum semua Guru sebagai sasaran penelitian memiliki pemahaman yang mendalam tentang standar proses pembelajaran. Hanya sebagian kecil guru baru yang memang mendapat pembekalan lewat pertemuan-pertemuan guru baru yang diisi informasi antara lain tentang standar proses termasuk pembelajaran koperatif dan kolaboratif. Keterbatasan referensi, keterbatasan kesempatan mengikuti penataran dan keterbatasan diseminasi hasil penataran serta tidak optimalnya pelaksanaan kegiatan kelompok kerja guru semakin mendorong kondisi yang tidak ideal. Penyusunan perencanaan pelaksanaan pembelajaran belum mengacu sepenuhnya pada standar proses dan pembelajaran kooperatif kolaboratif seperti yang tertera pada standar proses. Hal ini berpengaruh kepada tingkat keterlaksanaan kurikulum yang rendah. Disisi lain guru lama sudah sebagian besar mengerjakan administrasi guru kelas seuai pedoman admnistrasi guru kelas yang ada. 


\section{Deskripsi Hasil Siklus 1}

a. Tahap Perencanaan

Pada tahap ini penulis mempersiapkan pertemuan sesuai jadwal yang sudah disusun pada kunjungan kelas oleh Kelompok Kerja Kepala Sekolah (KKKS) Kecamatan Klambu Kabupaten Grobogan, perangkat pembelajaran yang terdiri dari Rencana Kegiatan-1 (RK-1), format-format penilaian, Rencana pelaksanaan pembelajaran yang disusun oleh guru kelas yang akan dikunjungi, Buku Standar Proses dan Foto copy pembelajaran kooperatif kolaboratif.

Pada tahap ini Kepala Sekolah dimana gurunya akan dikunjungi bertugas untuk membimbing dan mempersiapkan Rencana Pelaksanaan Pembelajaran masingmasing 6 (enam) set yang 5 set untuk guru kunjung yang akan melakukan observasi, pengamatan dan penilaian guru dan satu set untuk guru yang dikunjungi. Mempersiapkan ruang diskusi pasca pelaksanaan pembelajaran.

Tugas guru yang akan dikunjungi adalah mempersiapkan admnistrasi guru kelas, rencana pelaksanaan pembelajaran serta mempersiapkan pelaksanaan pembelajaran baik buku, peraga dan pendukung lainnya.

b. Tahap Pelaksanaan Kegiatan

Sebenarnya proses kunjungan dilaksanakan untuk semua guru dan semua kelas, namun yang dijadikan objek penelitian oleh peneliti hanya guru

Pelaksanaan teknik kunjungan antar kelas diatur dengan tahapan sebagai berikut : (1) Pertemuan persiapan, (2) Pengantar Oleh Pengawas, (3) Pembagian instrumen, (4) Pelaksanaan Pembelajaran, (5) Penilaian Rencana Pelaksanaan Pembelajaran dan pelaksanaan pembelajaran oleh Guru pengamat dan kepala sekolah, (6) Penilaian Admnistrasi Guru Kelas, (7) Mendiskusikan hasil pengamatan dan penilaian oleh guru dipimpin kepala sekolah yang sekolahnya dijadikan obyek pengamatan/penilaian.

\section{Deskripsi Siklus-2}

\section{a. Tahap Perencanaan}

Pada tahap ini peneliti mempersiapkan pertemuan sesuai jadwal yang sudah disusun pada kunjungan kelas oleh Kelompok Kerja Kepala Sekolah (KKKS) Kecamatan KlambuKabupaten Grobogan, perangkat pembelajaran yang terdiri dari Rencana Kegiatan -2 (RK-2), format-format penilaian kinerja, Rencana pelaksanaan pembelajaran yang disusun oleh guru pada sekolah yang akan dikunjungi dengan 
memperhatiakn revisi-revisi tndakan pada siklus-1, Buku Standar Proses dan Foto copy pembelajaran kooperatif kolaboratif.

Pada tahap ini Kepala Sekolah dimana gurunya akan dikunjungi bertugas untuk membimbing dan mempersiapkan Rencana Pelaksanaan Pembelajaran masingmasing 6 (enam) set. Masing-masing 5 set untuk guru kunjung yang akan melakukan observasi, pengamatan dan penilaian guru dan satu set untuk guru yang dikunjungi . Mempersiapkan ruang diskusi pasca pelaksanaan pembelajaran.

Tugas guru yang akan dikunjungi adalah mempersiapkan admnistrasi guru kelas, rencana pelaksanaan pembelajaran serta mempersiapkan pelaksanaan pembelajaran baik buku, peraga dan pendukung lainnya.

b. Tahap Pelaksanaan Kegiatan

Seperti pada siklus I yang dijadikan obyek penelitian oleh peneliti hanya guru kelas 5 (lima) yang langsung peneliti tangani.

Pelaksanaan teknik kunjungan kelas diatur dengan tahapan sebagai berikut : (1) Pertemuan persiapan, (2) Pengantar Oleh Pengawas, (3) Pembagian instrumen, (4) Pelaksanaan Pembelajaran, (5) Penilaian Rencana Pelaksanaan Pembelajaran dan pelaksanaan pembelajaran oleh Guru pengamat dan kepala sekolah, (6) Penilaian Admnistrasi Guru Kelas, (7) Mendiskusikan hasil pengamatan dan penilaian oleh guru dipimpin kepala sekolah yang sekolahnya dijadikan obyek pengamatan/penilaian.

\section{HASIL PENELITIAN}

\section{Siklus I}

Data hasil penelitian pada siklus-1 adalah meliputi :

a. Penilaian Perencanaan Pembelajaran guru didapatkan skor terendah 1, 6 dengan nilai 40,00 , skor rata-rata 2,33 dengan nilai 58,33 , skor tertinggi 2,47 dengan nilai 61,67

b. Penilaian Pelaksanaan Pembelajaran guru didapatkan skor terendah 2,20 dengan nilai 55,00 , skor rata-rata 2,60 dengan nilai 65,00 , skor tertinggi 2,98 dengan nilai 74,44

c. Tahap Pengamatan dilakukan oleh 1 orang yaitu teman sejawat (Kepala SD) dan Peneliti yang berfungsi sebagai penilai 1 dan 2. Hasil pengamatan didapatkan nilai terendah 70,83, nilai rata-rata 76,39 dan nilai tertinggi adalah 85,42.

d. Tahap Refleksi berupa Analisis Data Penelitian Siklus I secara garis besar dapat 
dilihat pada grafik dan analisa deskriptif sebagai berikut :

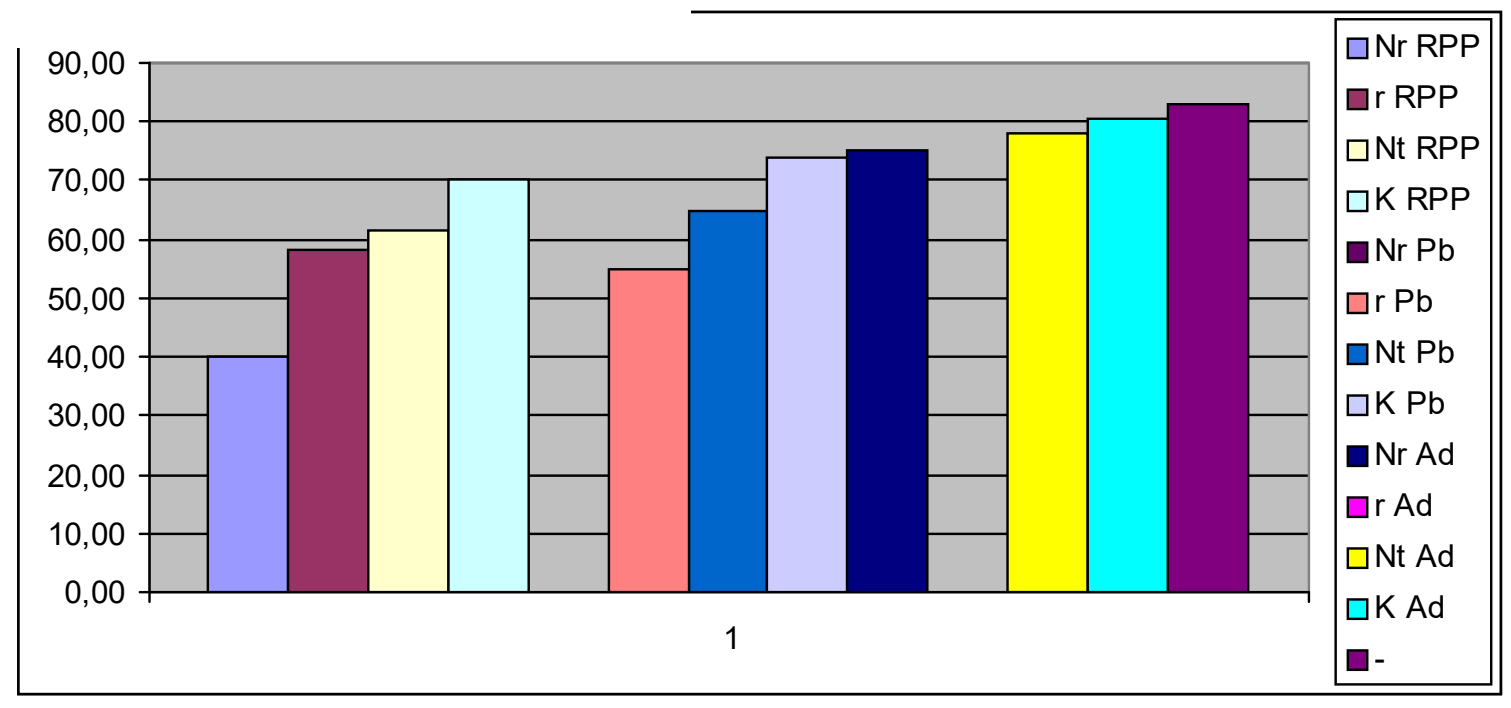

Gambar 1. Grafik Penilaian RPP, Pelaksanaan Pembelajaran, Administrasi Guru

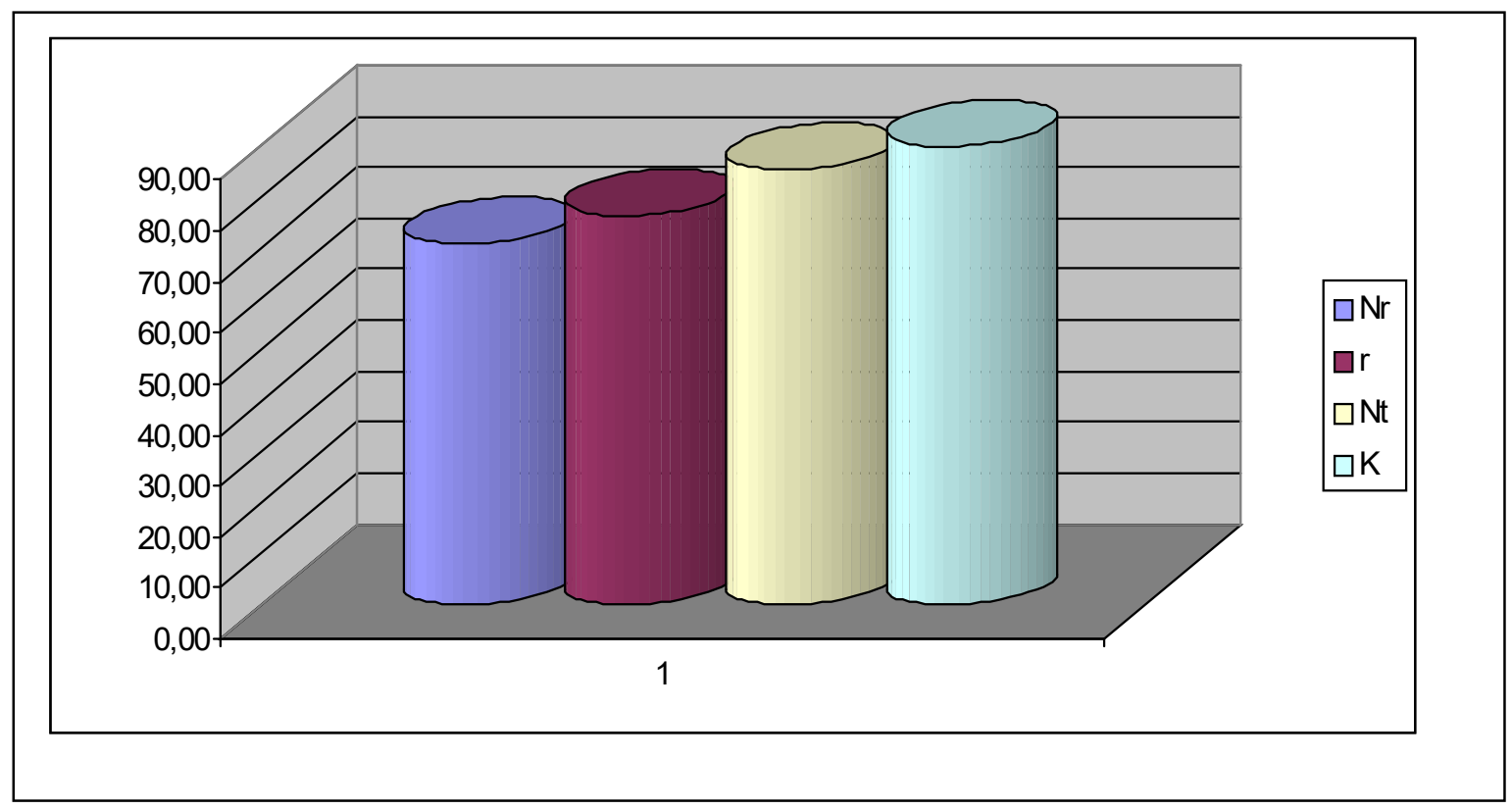

Gambar 2. Grafik Hasil Penilaian Pengamatan Kunjungan Antar kelas Siklus-1

a.) Dari hasil penilaian terhadap perencanaan pembelajaran, pelaksanaan pembelajaran, pelaksanaan kegiatan diperoleh hasil skor terendah 1, 6 dengan nilai 40,00 , skor rata-rata 2,33 dengan nilai 58,33 , skor tertinggi 2,47 dengan nilai 61,67 
Dari data tersebut dapat dideskripsikan bahwa :

$>$ pembuatan perencanaan pembelajaran belum memuaskan, kelemahan antara laian : materi pelajaran belum diuraikan dalam pokok-pokok materi yang rinci, belum jelas penggunidaan strategi pembelajaran yang digunakan dan evaluasi yang tidak lengkap

$>$.Perolehan nilai yang belum optimal bisa dipahami karena memang tingkat pemahaman para guru terkendala oleh beberapa alasan seperti minimnya referensi, minimnya kesempatan mengikuti diklat maupun diseminasi.. Hal ini disebabkan karena sebagian guru tahun sebelumnya belum pernah mengenal pembelajaran kooperatif kolaboratif, sedangkan sebagian yang lain karena Standar proses benar-benar baru didapat secara lengkap pada pertemuan siklus pertama.

b) Dari Hasil penilaian pelaksanaan pembelajaran adalah sebagai skor terendah 2,20 dengan nilai 55,00 , skor rata-rata 2,60 dengan nilai 65,00 , skor tertinggi 2,98 dengan nilai 74,44

Dari data tersebut dapat dideskripsikan hal-hal sebagai berikut :

> bahwa pelaksanaan pembelajaran belum memuaskan karena semua guru dibawah nilai kinerja yang ditetapkan yaitu 75

$>$ kelemahan antara lain : materi pelajaran hanya dicantumkan pokok materi saya dan belum diuraikan dalam pokok-pokok materi yang rinci, belum secara jelas nampak penggunaan strategi pembelajaran yang digunakan dan evaluasi yang kurang lengkap. Minimal ada soal dan jawaban juga dilengkapi kriteria penilaian.

c) Dari hasil penilaian administrasi guru kelas siklus-1 dengan Skor maksimal/ideal adalah 128 dan nilai maksimal adalah 100 di dapatkan hasil penilaian sebagai skor terendah 100 dengan nilai 78,00, skor rata-rata 103 dengan nilai 80,34, skor tertinggi 106 dengan nilai 82,81.

d) Sedangkan hasil pengamatan pada siklus-1 didapat nilai sebagai Nilai terendah 70,83 , nilai rata-rata 76,39 dan nilai tertinggi adalah 85,42 .

Aspek yang ada dalam kategori baik adalah pada kegiatan perencanaan dan kegiatan pelaksanaan diskusi. Pengamatan pada ketrampilan guru menunjukkan bahwa beberapa ketrampilan guru belum optimal jadi masih perlu ditingkatkan lagi . Batas kinerja untuk pelaksanaan kunjunganantar kelas ini adalah 80. 
Beberapa catatan penting pada siklus-1 adalah :

$>$ Guru yang dikunjungi pada umumnya bersemangat menunjukkan admnistrasi yang dibuat dan rencana pelaksanaan pembelajaran yang dikemas khusus untuk kunjungan kelas hal ini nampak pada kemasan admnistrasi yang dibuat dengan sangat baik.

Kepala Sekolah yang dikunjungi nampak berupaya sebaik mungkin agar guru binaannya atau guru yang dikunjungi tampil prima saat peleksanan pembelajaran.

Nampak sebagaian besar admnistrasi guru sudah dikerjakan tetapi ada beberapa jenis yang ternyata tidak dikerjakan, umumnya pada format perbaikan dan pengayaan, program bimbingan dan konseling, buku pribadi siswa, dan kelengkapan inventaris buku dan inventaris kelas.

Dari apa yang sudah dilaksanakan pada siklus -1 secara garis besar kegiatan kunjungan antar kelas sudah terlaksana dengan baik, namun perlu dilakukan perbaikan agar pelaksanaan pada siklus-2 atau putaran kedua dapat lebih meningkat.

C. Revisi Rancangan

Dalam pelaksanaan kegiatan pembelajaran diperoleh informasi dari hasil pengamatan sebagai berikut :

a. Guru perlu lebih memperdalam standar proses dan pembelajaran kooperatif kolaboratif dengan mengkaji ulang buku referensi standar proses dan pembelajaran administrasi guru kelas.

b. Kepala Sekolah lebih intensif memfasilitasi guru untuk mempersiapkan revisi-revisi pada penyusunan rencana pembelajaran.

c. Guru dan Kepala Sekolah hendaknya mendiskusikan masukan-masukan yang didapat pada saat diskusi pasca pelaksanaan pembelajaran agar pelaksanaan putaran ke-2 atau siklus-2 dapat lebih sempurna.

\section{Siklus II}

Data hasil penelitian pada siklus-2 adalah meliputi:

a. Hasil Penilaian Rencana Pembelajaran guru adalah sebagai berikut :Skor terendah 2,73 dengan nilai 68,33 , Skor rata-rata 3,00 dengan nilai 75,00 , Skor tertinggi 3,13 dengan nilai 78,33. Dari data tersebut dapat disimpulkan bahwa pembuatan perencanaan pembelajaran rata-rata sudah memenuhi nilai minimal standar kinerja yaitu 75, sedang nilai tertinggi adalah 78,33. Skor dan nilai untuk aspek bahan pelajaran, media pembelajaran dan evaluasi masih di bawah standar. Sementara 
untuk pelaksanaan pembelajaran kooperatif kolaboratif menunjukkan peningkatan yang tajam hal ini terjadi karena dalam kegiatan inti sudah dicantumkan metode pembelajaran yang rinci yang diambil dari buku 14 jenis motede pembelajaran yang disampaiakan pada siklus 1. Dari hasil sikulus 2 nampak bahwa belum ada perubahan mendasar pada guru dalam melengkapi isi perencanaan pembelajaran, seperti uraian materi dan kelengkapan evaluasi

b. HasilPenilaian Pelaksanaan Pembelajaran adalah Skor terendah 2,67 dengan nilai 66,67, Skor rata-rata 3,02 dengan nilai 75,56, Skor tertinggi 3,07 dengan nilai 76,67. Dari hasil penilaian administrasi guru kelas siklus-2 di dapatkan hasil penilaian Skor terendah 118 dengan nilai 92,19, Skor rata-rata 120 dengan nilai 93,36, Skor tertinggi 121 dengan nilai 94,53

c. Tahap Pengamatan

Pengamatan atau observasi dilakukan oleh 2 orang yaitu teman sejawat (Pengawas TK/SD) dan Peneliti yang berfungsi sebagai penilai 1 dan 2. Perolehan nilai pengamatan pada siklus-2 Nilai terendah 79,17 , Nilai rata-rata 84,72 , Nilai tertinggi adalah 91,67

d. Tahap Refleksi

Data hasil penilaian dan pengamatan pada siklus-2 dapat dilihat pada grafik dan paparan sebagai berikut :

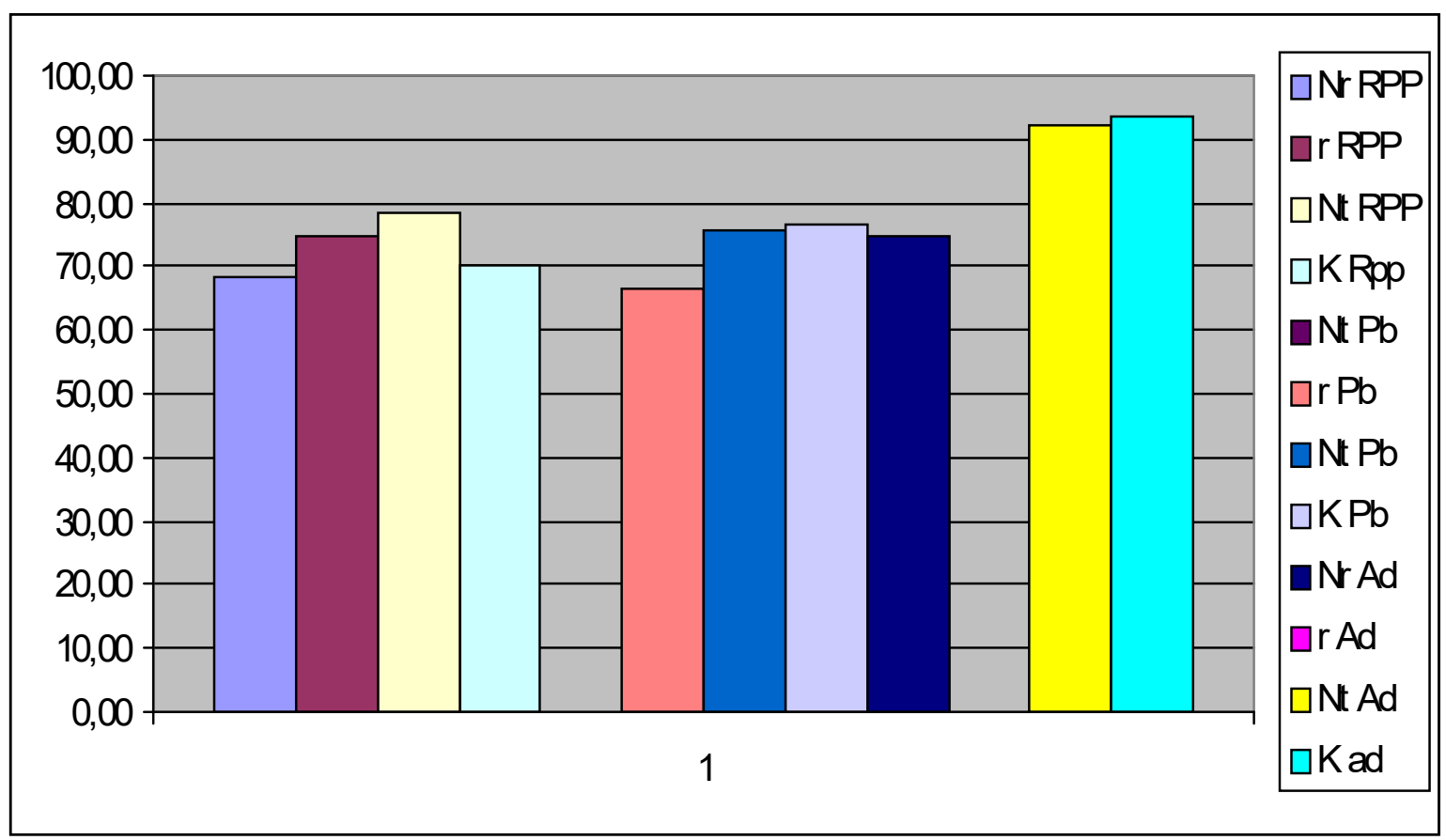

Gambar 3. Grafik Penilaian RPP, Pelaksanaan Pembelajaran, Adminis trasi Guru 


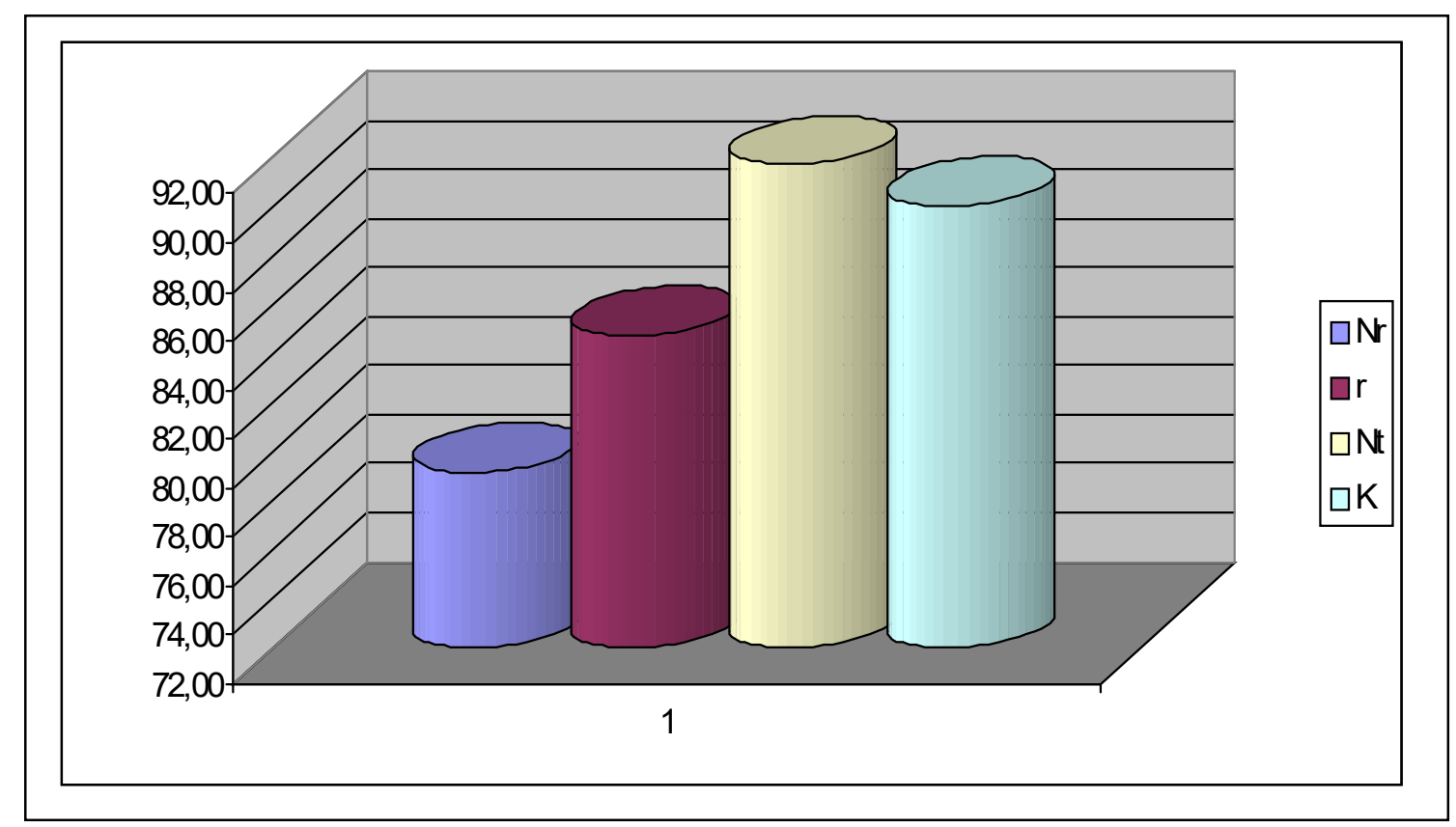

Gambar 4. Grafik Hasil Penilaian Pengamatan Kunjungan Antar kelas Siklus-2

Analisis Data hasil Penelitian pada akhir Siklus-2 Dari hasil penilaian terhadap perencanaan pembelajaran, pelaksanaan pembelajaran, pelaksanaan kegiatan diperoleh hasil Penilaian Perencanaan Pembelajaran Skor terendah 2,73 dengan nilai 68,33 , Skor rata-rata 3,00 dengan nilai 75,00, Skor tertinggi 3,13 dengan nilai 78,33. Dari data tersebut dapat dideskripsikan bahwa :

- Pembuatan perencanaan pembelajaran pada siklus-2 rata-rata sudah memenuhi nilai minimal standar kinerja yaitu 75 , sedang nilai tertinggi adalah 78,33.

- Skor dan nilai untuk aspek bahan pelajaran dan media pembelajaran dan evaluasi masih dapat berubah drastis, kelemahan antara lain : masih pada aspek materi pelajaran belum diuraikan dalam pokok-pokok materi yang rinci, belum jelas penggunaan strategi pembelajaran yang digunakan dan evaluasi yang tidak lengkap.

- Untuk aspek rencana pelaksanaan pembelajaran kooperatif kolaboratif menunjukkan peningkatan yang tajam hal ini terjadi karena dalam kegiatan inti sudah dicantumkan metode pembelajaran yang rinci yang diambil dari buku 14 jenis motede pembelajaran yang disampaiakan pada siklus 1. Dari hasil sikulus 2 
nampak bahwa belum ada perubahan mendasar pada guru dalam melengkapi isi perencanaan pembelajaran, seperti uraian materi dan kelengkapan

b. Dari Hasil penilaian pelaksanaan pembelajaran Skor terendah 2,67 dengan nilai 66,67 , Skor rata-rata 3,02 dengan nilai 75,56, Skor tertinggi 3,07 dengan nilai 76,67

Dari data tersebut dapat dideskripsikan hal-hal sebagai berikut :

- bahwa pelaksanaan pembelajaran walau belum optimal namun rata-rata sudah memenuhi nilai kinerja yang ditetapkan yaitu 75 .

- masih ada 2 peserta yang masih di bawah standar karena pada aspek materi pelajaran hanya dicantumkan pokok materi saya dan belum diuraikan dalam pokokpokok materi yang rinci, disamping itu belum secara jelas nampak penggunaan strategi pembelajaran yang digunakan dan evaluasi yang kurang dilengkapi kriteria penilaian.

c. Hasilpengamatan pada siklus-2 didapat nilai sebagai berikut : nilai terendah 79,17 , nilai rata-rata 84,72 dan nilai tertinggi adalah 91,67.

Dari data tersebut nampak ada kenaikan yang signifikan pada pelaksanaan kegiatan ini, hal ini menunjukkan bahwa kegiatan kunjungan kelas mendapat respon positif dan bisa lebih dikembangkan pada kegiatan di lain kesempatan.

d. Revisi Rancangan Pelaksanan kegiatan belajar pada Siklus-2 II ini masih terdapat beberapa aspek yang perlu disempurnakan. Maka perlu adanya revisi untuk dilaksanakan jika akan dilaksanakan sikklus 2. Namun untuk kegiatan penelitian ini hanya berlangsung 2(dua) siklus, sehingga revisi untuk digunakan pada siklus-3 ditiadakan.

\section{PEMBAHASAN}

\section{Ketuntasan Hasil Peningkatan Kompetensi Guru}

Berdasarkan data penelitian ini menunjukkan adanya peningkatan-peningkatan kompetensi guru dalam meningkatkan 3(tiga ) kompetensi tersebut diatas ( meningkat dari siklus-1, dan siklus-2 )

a. Kompetensi pembuatan Rencana Pelaksanaan Pembelajaran meningkat dari ratarata 58,33 pada siklus 1 menjadi 75 pada siklus 2 .

b. Kompetensi Guru dalam penyusunan Rencana Pelaksanan Pembelajaran (RPP) berdasarkan analisis data menunjukkan bahwa kompetensi guru dalam menyusun RPP secara bertahap meningkat. Dengan pencapaian nilai tertinggi 78 dan, terendah 68,33 dan nilai rata-rata yang di dapat yaitu 75,00 menunjukkan bahwa 
sudah diatas $80 \%$ guru ( $80,33 \%$ ) yang sudah menyusun RPP sesuai kaidah yang ditetapkan. Ada 1 guru yang nilainya masih belum memenuhi ketentuan dengan nilai 66,67. Jadi sudah ada perbaikan nyata upaya guru dalam rangka mengimplementasikan standar proses dan pembelajaran kooperatif pada perencanaan pembelajaran. Implikasinya terhadap komitmen untuk membuat RPP yang memenuhi standar semakin kuat, revisi-revisi terhadap penyusunan RPP yang menunjukkan hasil yang cukup menggembirakan hal ini nampak bahwa akhir siklus-2 hanya 16,66 \% atau satu orang guru saja yang belum seperti yang diharapkan. Namun catatan penting yang harus dilakukan para guru adalah mencantumkan bahan ajar ataua materi pelajaran dengan lebih detail atau rinci, dan juga dalam pemilihan media perlu lebih dikembangkan.

c. Kompetensi pelaksanaan pembelajaran meningkat dari rata-rata 65,00 pada siklus 1 menjadi 75,56 pada siklus 2

Kompetensi Guru dalam penyusunan Pelaksanan Pembelajaran berdasarkan analisis data menunjukkan bahwa kompetensi guru dalam melaksanakan pembelajaran secara bertahap meningkat . Dengan pencapaian nilai tertinggi 83,3 dan, terendah 68,3 dan nilai rata-rata yang di dapat yaitu 75,56 menunjukkan bahwa sudah diatas $50 \%$ guru ( $66,66 \%$ ) yang sudah melaksanakan pembelajaran sesuai kaidah yang ditetapkan. Ada 2 guru yang nilainya masih belum memenuhi ketentuan bergerak antara 68,3 dan 69,2. Jadi sudah ada perbaikan nyata upaya guru dalam rangka mengimplementasikan standar proses dan pembelajaran kooperatif pada pelaksanaan pembelajaran. Implikasinya terhadap komitmen untuk melaksanakan pembelajaran yang memenuhi standar semakin kuat, revisi-revisi terhadap praktek pelaksanaan pembelajaran menunjukkan hasil yang cukup menggembirakan hal ini nampak bahwa akhir siklus-2 hanya 33,33\% atau dua guru saja yang belum seperti yang diharapkan. Namun catatan penting yang harus dilakukan para guru dalam pelaksanaan pembelajaran adalah perlunya peningkatan lebih lanjut komptenesi dalam menggunakan media pembelajaran , dan evaluasi pembelajaran.

d. Kompetensi Pengerjaan Adminstrasi Guru Kelas pada akhir siklus-2 menunjukkan bahwa admnistrasi guru kelas sudah dikerjakan semuanya.

e. Persepsi guru mengenai supervisi kolegial dengan teknik kunjungan antar kelas dapat dilihat pada Tabel 2.4 Kuesioner mengenai kunjungan antar kelas yang dibagikan kepada para guru peserta pada siklus-2 bertujuan untuk mendapatkan

> | Wardana | Peningkatkan Kompetensi Guru Sekolah Dasar Dalam Mengimplementasikan Standar Proses Pembelajaran Melalui Supervisi Kolegial Teknik Kunjungan Antar Kelas 
informasi mengenai sejauhmana persepsi guru terhadap pemanfaatan kunjungan antar kelas, hubungannya kunjungan antar kelas terhadap beberapa ketrampilan guru dalam hal penguasan pembelajaran kooperatif seperti ketrampialn bekomunikasi dan bekerjasana, peningkatan kepercayaan diri dan rasa tanggung jawab, serta sikap mandiri, kreatifitas guru, keinginan mengerjakan admninistrasi kelas dengan lebih baik menyampaikan informasi, kemampuan mengerjakan tugas dalam penyusunan RPP yang standar serta sensitivitas dan toleran antar anggota kelompok.

f. Para guru yang menyatakan "Sangat setuju" dan "setuju " dikelompokkan sebagai guru yang amat memahami teknik kunjungan antar kelas. Guru yang menyatakan "Kurang setuju " dikelompokkan sebagai guru yang cukup memahami kunjungan antar kelas. Guru yang menyatakan "Tidak setuju " atau dikelompokkan sebagai guru yang kurang memahami. Sedangkan guru yang menyatakan "'ragu-ragu"” dikelompokkan sebagai guru yang tidak memahami makna penting kunjungan antar kelas sebagai model yang dapat meningkatkan kompetensi guru.

Secara keseluruhan dengan mendasarkan pada semua indikator pemahaman teknik kunjungan antar kelas, "sangat setuju" skor 200 dengan nilai prosentase 66,66 $\%$ dan "setuju" skor 128 dengan nilai prosentase 33,33\% jika dikombinasikan maka akan terdapat tingkat pemahaman yang tinggi (100\%). Dengan hasil seperti ini, kiranya masuk akal apabila pada siklus 2 para guru mampu mencapai peningkatan dalam skor pemahaman materi dibandingkan dengan siklus pertama.

Pada pernyataan dengan kategori amat memahami yang disampaikan para guru terlihat bahwa sebagian terbesar menyatakan bahwa kunjungan antar kelas memotivasi guru untuk menguasai pembelajaran kooperatif (1), memotivasi guru untuk mendorong dan membantu kelompoknya untuk menguasai ketrampilanketrampilan mengajar(11) dan untuk mengerjakan tugas penyusunan RPP yang standar.(12)

Motivasi tersebut sangat penting bagi guru itu sendiri dan juga Kepala Sekolah dalam rangka meningkatkan kinerja guru yang tentu akan berdampak positif terhadap mutu atau kualitas pembelajaran guna mewujudkan kualitas pendidikan pada umumnya

Disamping itu peningkatan berkomunikasi dan bekerjasama (2) tanggung jawab, (4) memecahkan masalah pembelajaran (6), serta terbangunnya sensitivitas dan toleransi antar anggota kelompok (10) akan membantu meningkatkan semangat 
kerja dengan dilandasi semangat kooperatif kolaboratif untuk maju dan berkembang bersama .

Mengenai peningkatan perasaan mandiri (5) dan percaya diri(3) pada para guru sebagai hasil penggunaan teknik kunjungan antar kelas, para guru dapat diandalkan untuk lebih mampu menjadi sumberdaya yang berkualitas. memiliki Motivasi sifat mandiri sebagai landasan yang kokoh sebagai agen pembelajaran yang mengedepankan profesionalisme guru.

Pernyataan yang disampaikan guru yang tidak kalah pentingnya dalam rangka menumbuhkembangkan guru yang berkualitas adalah kreativitas dalam proses pembelajaran (7). Mereka menyatakan dengan model kunjungan antar kelas dapat menumbuhkan kreativitas. Meskipun pada prinsipnya sifat kreatif dapat ditanamkan pada seseorang dengan memakan waktu yang cukup lama dan melalui pembiasaan bertahap dan terprogram, hasil intervensi dalam penelitian ini cukup memberikan harapan. Pada literatur-literatur dan penelitian tentang masyarakat yang maju, masyarakat yang maju adalah sebagian ditentukan oleh kreativitas yang berkembang pada para anggota masyarakat itu

Hal penting lainnya seperti yang diungkapkan para guru adalah perasaan senang ketika disupervisi dengan menggunakan teknik kunjungan antar kelas (pernyataan 8). Proses pendidikan yang diiringi perasaan senang para pebelajarnya merupakan proses pembelajaran yang produktif. Perasaan-perasaan positif yang melandasi para pebelajar memungkinkan mengarah pada hasil pembelajaran yang produktif. Pada teori-teori psikologi pendidikan yang mutakhir, pembelajaran yang produktif akan mengantarkan para guru sebagai peserta Kelompok kerja guru pada kepribadian yang matang dari berbagai dimensi. Para guru yang berkategori amat memahami menganggap bahwa kunjungan antar kelas sering dapat digunakan untuk mengemukakan ide, gagasan dan pendapat dengan bebas ide-ide baru penting dalam upaya meningkatkan ketrampilan guru untuk mengungkap ide dan gagasan yang selama ini dinilai melemah.

Pernyataan guru bahwa dengan kunjungan antar kelas memotivasi dan mendorong dan membantu satu sama lain untuk menguasai keterampilanketerampilan mengajar(11) menunjukkan bahwa semangat kerjasama yang diperlukan untuk pengembangan kurikulum bersama sudah memiliki basis yang kuat, karena pengembangan kurikulum hanya berkembang secara komprehensif manakala ada kerjasama seluruh komponen sekolah.

> | Wardana | Peningkatkan Kompetensi Guru Sekolah Dasar Dalam Mengimplementasikan Standar Proses Pembelajaran Melalui Supervisi Kolegial Teknik Kunjungan Antar Kelas 
Yang tak kalah pentingnya adalah pernyataan guru bahwa melalui kunjungan antar sekolah maka guru termotivasi untuk mengerjakan tugas penyusunan RPP yang standar adalah selaras dengan tuntutan profesionalisme. Bagaimanapun rencana pembelajaran adalah design pembelajaran yang merupakan unsur amat penting dan yang akan mewarnai proses pembelajaran guna perolehan hasil (outcome ) yang optimal.

\section{KESIMPULAN}

Berdasarkan hasil penelitian yang telah dipaparkan selama dua siklus, hasil seluruh pembahasan serta analisis yang telah dilakukan dapat disimpulkan sebagai berikut (1) Supervisi kolegial teknik kunjungan antar kelas memiliki dampak positif dalam meningkatkan kompetensi Guru dalam melaksanakan standar proses pembelajaran dan pembelajaran kooperatif kolaboratif yang ditandai dengan peningkatan kompetensi perencanaan pelaksanaan pembelajaran, yaitu siklus I ratarata58,33 menjadi rata-rata 75 pada siklus II. (2) Supervisi kolegial teknik kunjungan antar kelas memiliki dampak positif dalam meningkatkan kompetensi Guru dalam melaksanakan standar proses pembelajaran dan pembelajaran kooperatif kolaboratif yang ditandai dengan peningkatan kompetensi guru dalam pelaksanaan pembelajaran, yaitu siklus I rata-rata 65,00 menjadi rata-rata 75,56 pada siklus II. (3) Supervisi kolegial teknik kunjungan antar kelas memiliki dampak positif dalam meningkatkan kompetensi Guru dalam melaksanakan pengerjaan admnistrasi guru kelas yang ditandai dengan peningkatan kompetensi guru dalam pengerjaan admnistrasi guru kelas, yaitu siklus I rata-rata 70,00 menjadi rata-rata $95 \%$ pada siklus II.(4) Supervisi kolegial teknik kunjungan antar kelas memiliki dampak positif dalam meningkatkan kinerja guru yang ditandai dengan pernyataan termotivasi untuk menguasai pembelajaran kooperatif, rong dan membantu sesame anggota kelompok, mengerjakan RPP dan admnistrasi sekolah dengan lebih baik.(5) Supervisi kolegial teknik kunjungan antar kelas memiliki dampak positif dalam meningkatkan kualitas guru yang ditandai dengan pernyataan adanya peningkatkan rasa percaya diri, rasa tanggung jawab, lebih kreatif dalam proses pembelajaran, serta dapat memecahkan masalah dalam proses pembelajaran .

Beberapa saran dari penelitian ini diantaranya adalah untuk meningkatkan profesionalisme guru khusus kompetensi Guru dalam melaksanakan standar proses pembelajaran , pembelajaran kooperatif kolaboratif dan pengerjaan admnistrasi guru 
kelas perlu dicarikan model yang tepat dan mudah sehingga kegiatan KKG dapat lebih optimal, dan untuk itu maka superviisi kolegial dengan teknik kunjungan antar kelas sangat sesuai untuk digunakan dalam optimalisasi KKG sebagai wahana peningkatan profesionalisme guru.

Supervisi kolegial teknik kunjungan antar kelas dapat dilakukan oleh para Kepala Sekolah terhadap guru dan juga kepala sekolah mulau perencanaan pembelajaran, pelaksanaan pembelajaran dan admnistrasi guru kelas sebagai pendukung keberhasilan proses pembelajaran

\section{DAFTAR PUSTAKA}

Anita Lie. 2010. Cooperative Learning, Mempraktikkan Cooperative Leraning di Ruang Kelas. PT Gramedia Widasarana Indonesia, Jakarta.

Burhanuddin, Effendi, et.al. 1995. Profesi Keguruan. Malang: IKIP Malang Haris. 1997. Competency-based Education and Training, University of South Australia Mulyasa, E. 2005.Implementasi Kurikulum 2004, Panduan Pembelajaran KBK. Remaja Rosdakarya, Bandung

Nur, Muh. 2001. Pemotivasian Siswa untuk Belajar. University Press, Universitas Negeri Surabaya, Surabaya

Rachman,Edmund. 2005. Berfikir Kritis dan Inovatif. Prestasi Pustakarya, Jakarta.

Safaat,Asep. 2006. Kemantapan diri dan Kompetensi Mengajar, www.pikiranrakyat.com/cetak0504/181104htm

Sagala,Syaiful. 2003. Konsep dan Makna Pembelajaran. Alfabeta, Bandung

Slavin,Robert,E. 2010.Cooperative Learning, Teori, Riset dan Praktik, Penerbit Nusa Media, Bandung

Soedijarto. 1989. Menuju Pendidikan Nasional yang Relevan dan bermutu. Gramedia, Jakarta

Soelihatin,Etin. 2007. Cooperative Learning. PT Bumi Aksara, Jakarta

Sugiyanto. 2010. Model-Model Pembelajaran Inovatif. Yuma Pustaka dan FKIP UNS, Surakarta.

Sukidin, dkk. 2002. Manajemen Penelitian Tindakan Kelas, Insan Cendekia, Surabaya Supriyono,Agus. 2009. Cooperative Leraning, Teori dan Aplikasi PAKEM. Pustaka Pelajar,Yogyakarta.

Sutomo. 1993. Dasar-dasar Interaksi Belajar Mengajar, Usaha Nasional, Surabaya 
II2 | Jurnal Tarbawi Vol. 15. No. I. Januari - Juni 2018

Undang-Undang Republik Indonesia Nomor 20 Tahun 2003 : Tentang Sistem Pendidikan Nasional (2006). : Fokusmedia, Jakarta

Undang-Undang Republik Indonesia Nomor 14 Tahun 2005 : Tentang Guru dan Dosen,PB PGRI,Jakarta.

Surakhmad,Winarno. 2003. Memfasilitasi Pembelajaran yang berkualitas, Ditjen Dikdasmen Depdiknas-JICA, Jakarta 